REVIEW ARTICLE

ARTIGO DE REVISÃO

\title{
Current global scenario of guidelines on the management of paroxysmal nocturnal hemoglobinuria: a systematic literature review
}

\author{
Cenário global de diretrizes para o manejo da hemoglobinúria \\ paroxística noturna: uma revisão sistemática da literatura
}

Rodolfo Daniel de Almeida Soares'1, Patricia Belintani Blum Fonseca², Kleber Yotsumoto Fertrin ${ }^{3}$, André Marinato ${ }^{4}$ Andresa Lima Melo ${ }^{5}$, Ana Clara Kneese Nascimento 6 , Adrienne Bunn Moreno 7 , Antonianna Vecina ${ }^{8}$, Bruno Vieira Dias ${ }^{9}$, Carlos Bernardo Loureiro Lima ${ }^{10}$, Fernando Vieira Pericole de Souza ${ }^{11}$, Lucas Oliveira Cantadori' ${ }^{12}$, Marcos Laercio Ponte Reis ${ }^{13}$, Paulo Roberto Ganacini'14, Ricardo Helman ${ }^{15}$

DOI: 10.21115/JBES.v12.n2.p281-90

\section{Keywords:}

hemoglobinuria, paroxysmal, guideline, review, eculizumab, hematopoietic stem cell transplantation

\begin{abstract}
Objective: To report the outcomes of a systematic literature review of guidelines and consensus on the management of paroxysmal nocturnal hemoglobinuria (PNH) and describe the main therapeutic options available worldwide. Methods: A systematic literature review was conducted in April 2018 with no time limit and reported in line with the PRISMA statement. The AGREE II instrument was used to determine the quality of each guideline included in the systematic review. Results: Eight guidelines/consensus were eligible, one developed by an international group, two in Spain, and one each in Turkey, Germany, Argentina, Australia and the United Kingdom. Supportive treatment with erythrocyte transfusion, anticoagulants and steroids is indicated by all guidelines and consensus. The use of erythropoietin is suggested by three of them. Recommendations for the prescription of eculizumab were consistent in all but one guideline, published in 2005. Allogeneic hematopoietic stem cell transplantation is reported as the only potentially curative treatment for $\mathrm{PNH}$, although its association with high mortality and morbidity rates is emphasized, being indicated for a selected group of patients. The AGREE II scores applied for each domain showed in general a low and heterogeneous methodological quality among guidelines. Conclusion: Despite the low and heterogeneous methodological quality, in general the comparison of guidelines and consensus for PNH management showed consistent recommendations regarding supportive care, eculizumab and hematopoietic stem cell transplantation.
\end{abstract}

Received on: 05/22/2020. Approved for publication on: 07/01/2020

1. Universidade Federal do Rio Grande do Norte, Hospital Universitário Onofre Lopes, Unidade Transfusional, Natal, RN, Brazil. 2. Hospital Infantil Darcy Vargas, São Paulo, SP, Brazil.

3. Hematology and Hemotherapy Center, Universidade de Campinas, Campinas, SP, Brazil.

4. Flow Diagnósticos.

5. Unidade de Transplante de Medula Óssea do Instituto de Cardiologia do Distrito Federal (ICDF), Brasília, DF, Brazil.

6. Santa Casa de São Paulo, São Paulo, SP, Brazil.

7. Hospital Universitário Clementino Fraga Filho, Universidade Federal do Rio de Janeiro, Rio de Janeiro, RJ, Brazil.

8. Conjunto Hospitalar de Sorocaba e Faculdade de Ciências Médicas e da Saúde da Pontifícia Universidade Católica de São Paulo São Paulo, SP, Brazil.

9. Centro de Hematologia e Hemoterapia de Santa Catarina - HEMOSC, Florianópolis, SC, Brazil.

10. Hemorio, Rio de Janeiro, RJ, Brazil.

11. Hematology and Hemotherapy Center, Universidade de Campinas, Campinas, SP, Brazil.

12. Universidade Estadual Paulista - Unesp, Botucatu, SP, Brazil.

13. Ophir Loyola Hospital and Blood Center, Belém, PA, Brazil.

14. Hospital de Base Dr. Ary Pinheiro, Porto Velho, RO, Brazil.

15. Hospital Israelita Albert Einstein, Hospital BP, São Paulo, SP, Brazil.

Institution where the research was conducted: SENSE Company, São Paulo, SP, Brazil.

Conferences where the study was presented: No presentations to date.

Conflicts of interest: RDAS: Speaker for Alexion Pharmaceuticals Inc. PBBF: Speaker for Alexion Pharmaceuticals Inc. KYF: Speaker for Alexion Pharmaceuticals Inc. and received honoraria from ApoPharma Inc. AM: Speaker for Alexion Pharmaceuticals Inc. ALM: Speaker for Alexion Pharmaceuticals Inc. ACKN: Speaker for Alexion Pharmaceuticals Inc. ABM: Speaker for Alexion Pharmaceuticals Inc. AV: Speaker for Alexion Pharmaceuticals Inc. and Janssen Pharmaceuticals. BVD: Speaker for Alexion Pharmaceuticals Inc. CBLL: Speaker for Alexion Pharmaceuticals Inc. and Novartis. FVPS: Speaker for Alexion Pharmaceuticals Inc. LOC: Speaker for Alexion Pharmaceuticals Inc., AMGEN and Janssen Pharmaceuticals. MLPR: Speaker for Alexion Pharmaceuticals Inc., Amgen and Janssen Pharmaceuticals. PRG: Speaker for Alexion Pharmaceuticals Inc. and Janssen Pharmaceuticals. RH: Speaker for Alexion Pharmaceuticals Inc. and Janssen Pharmaceuticals. Disclaimer: This article has received funding for medical writing from Alexion Pharmaceuticals.

Corresponding author: Rodolfo Daniel de Almeida Soares. Hospital Universitário Onofre Lopes - Unidade Transfusional. Av. Nilo Peçanha, 620 - Petrópolis, Natal, RN, Brazil.CEP: 59.012-300.E-mail: rodolfodsoares@yahoo.com.br 


\section{Palavras-chave:}

hemoglobinúria paroxística, guia, revisão, eculizumabe, transplante de células-tronco hematopoéticas

\begin{abstract}
RESUMO
Objetivo: Relatar os desfechos de uma revisão sistemática da literatura de diretrizes e documentos de consenso sobre o manejo da hemoglobinúria paroxística noturna (HPN) e descrever as principais opções terapêuticas disponíveis mundialmente. Métodos: Uma revisão sistemática da literatura foi conduzida em abril de 2018 sem limite temporal e realizada de acordo com a recomendação PRISMA. O instrumento AGREE II foi utilizado para determinar a qualidade de cada diretriz incluída na revisão. Resultados: Foram elegíveis oito diretrizes/consensos, um desenvolvido por um grupo internacional, dois na Espanha e um em cada um dos países a seguir: Turquia, Alemanha, Argentina, Austrália e Reino Unido. O tratamento de suporte com transfusão de eritrócitos, anticoagulantes e esteroides é indicado por todos os documentos. A eritropoetina é indicada por três deles. A recomendação de prescrição do eculizumabe foi consistente em todos, exceto em um publicado em 2005. O transplante alogênico de células-tronco hematopoéticas é reportado como o único tratamento com potencial curativo para a HPN, apesar de uma enfática associação com maiores taxas de mortalidade e morbidade, sendo indicado para grupos selecionados de pacientes. Os escores AGREE II aplicados para cada domínio demonstraram, em geral, qualidade metodológica baixa e heterogênea entre as diretrizes. Conclusão: Apesar da qualidade metodológica baixa e heterogênea, em geral, a comparação de diretrizes e consensos para o manejo da HPN demonstrou recomendações consistentes quanto ao uso de tratamento de suporte, eculizumabe e transplante alogênico de células-tronco hematopoiéticas.
\end{abstract}

\section{Introduction}

Paroxysmal nocturnal hemoglobinuria (PNH) is a rare acquired disease of hematopoietic stem cells (Parker, 2012). It was first described in the 18th century as a distinct clinical entity from both paroxysmal cold hemoglobinuria and march hemoglobinuria (Parker, 2008). PNH is typically characterized by the clinical triad of hemolytic anemia, thrombophilia and bone marrow failure (Risitano \& Rotoli, 2008; Parker et al., 2005).

PNH has been documented globally, although precise prevalence data are not available. Males and females are equally affected by the disease, which can occur in any phase of life, with greater incidence in adults under 40 years of age. The median age at diagnosis is 40.6 years for classic PNH and 34.5 years for aplastic anemia PNH syndrome (De Latour et al., 2008). The median survival time is 22 years and the 10year survival rate in patients with $\mathrm{PNH}$ ranged from $50 \%$ for patients diagnosed in the mid-20th century to over $70 \%$ in a more recent series, achieving $76.3 \%$ in a French study 10 years after the diagnosis (De Latour et al., 2008; Socié et al., 2016).

The deficiency of two glycosylphosphatidylinositol-anchored proteins (GPI-APs), CD55 and CD59, leads to red blood cell susceptibility to complement that accounts for hemolysis and is implicated in the tendency for patients to have thromboses (Hillmen et al., 1995; Brodsky, 2014). A somatic mutation in the X-linked phosphatidyl-inositol glycan class A (PIG-A) gene in patients with PNH impairs the encoding of the subunit A of phosphatidylinositol $\mathrm{N}$-acetylglucosaminyltransferase, one of the enzymes required for the synthesis of GPI anchors (Hill et al., 2013; Villegas et al., 2016) The diagnosis of PNH is currently made by flow cytometry studies demonstrating the presence of peripheral blood cells with absence of at least two cell surface markers anchored by GPI (Villegas et al., 2016).

PNH is classified into three subcategories: (1) classic PNH, which includes clinical evidence of hemolytic and thrombotic events and no evidence of another defined bone marrow abnormality; (2) PNH in the setting of other primary bone marrow disorders, in which patients have evidence of a PNH clone and also present a concomitant underlying bone marrow disorder, such as aplastic anemia, myelodysplastic syndrome or other bone marrow disorder; and (3) subclinical PNH, in which patients present small populations of GPI-AP deficient hematopoietic cells but no clinical or laboratory evidence of hemolysis or thrombosis (Parker et al., 2005; Brodsky, 2014).

Thrombosis is the most frequent complication of $\mathrm{PNH}$ and leads to severe morbidity and mortality (Brodsky, 2014; Hill et al., 2013). Besides thrombosis, the main presentations of classic PNH include non-immune hemolytic anemia, smooth muscle dystonia and bone marrow failure (Morado, 2010).

Allogeneic hematopoietic stem cell transplantation is the only potentially curative therapy for $\mathrm{PNH}$, which is associated with substantial early transplant-related mortality, and depends on the patient eligibility and availability of a HLA-compatible donor; therefore, many patients still receive supportive treatment (Risitano \& Rotoli, 2008; Hillmen et al., 1995). In addition, transplantation is better indicated when the patient has a component of bone marrow failure like aplastic anemia or myelodysplastic syndrome instead of classic PNH. Recent advances in post-transplant supportive care, applications of high-resolution HLA typing for donor selection and less toxic conditioning regimens have improved the outcomes of allogeneic stem cell transplantation, achieving a 5-year overall survival rate of 87.9\% (Lee et al., 2017).

A major therapeutic advance occurred in 2007 with the approval of eculizumab, a recombinant humanized monoclonal anti-C5 antibody, for PNH treatment by both the Food and Drug Administration and European Medicines Agency. Eculizumab stabilizes hemoglobin levels and reduces transfusion requirements and symptoms related to smooth muscle dysfunction, decreasing asthenia and significantly 
improving the quality of life. It has also been shown to reduce the relative risk of thromboembolism by $85 \%$ and the risk of thrombotic events in patients treated with anticoagulants by 94\% (Brodsky et al., 2008; Hillmen et al., 2007). In a UK cohort with more than 10 years of experience a significant improvement in survival for $\mathrm{PNH}$ patients receiving eculizumab was observed. This cohort of all PNH patients treated with eculizumab in the UK demonstrates the impact of eculizumab on the quality of life, reduction in complications and thereby improved survival for patients (Hill et al., 2012).

Due to advances in the knowledge of $\mathrm{PNH}$ natural history and its treatment, the standardization of guidelines is necessary for clinical action. Furthermore, some of the limitations of clinical trials in patients with rare diseases include small sample size, short follow-up and difficulty in identifying the ideal clinical outcomes (Gliklich et al., 2014).

The aim of this manuscript is to report the outcomes of a systematic literature review of guidelines and consensus on the management of $\mathrm{PNH}$ and describe the main therapeutic options available worldwide. The methodological quality of the guidelines and consensus was also evaluated.

\section{Methods}

\section{Search strategy}

A systematic literature review was conducted in The Cochrane Library, MEDLINE (via PubMed), Latin American and Caribbean Literature on Health Sciences (LILACS) and Centre for Reviews and Dissemination (CRD) databases from the earliest record until April 2018, with no time limit. Manual search was conducted on websites of health technology assessment agencies, related institutions and their databases. Search engines included Google and other online tools. Electronic searches were complemented by manual searches of bibliographic references and abstracts of selected publications. Additionally, four databases of evidence-based clinical practice guidelines were manually searched: National Guideline Clearinghouse (United States of America), Canadian Medical Association Infobase (Canada), Scottish Intercollegiate Guidelines Network (United Kingdom), and Guidelines International Network.

The following strategy was applied to PubMed and adapted for other databases according to the specialties of each one: (("'Hemoglobinuria, Paroxysmal"[Mesh] OR "Paroxysmal Hemoglobinuria" OR "Paroxysmal Nocturnal Hemoglobinuria" OR "Hemoglobinuria, Paroxysmal Nocturnal" OR "Marchiafava-Micheli Syndrome" OR "Marchiafava Micheli Syndrome" OR "Syndrome, MarchiafavaMicheli" OR "Paroxysmal Hemoglobinuria, Nocturnal" OR "Hemoglobinuria, Nocturnal Paroxysmal" OR "Nocturnal Paroxysmal Hemoglobinuria"))) AND (Clinical pathway[mh] OR Clinical protocol[mh] OR Consensus[mh] OR Consensus development conferences as topic[mh] OR Critical pathways[mh]
OR Guidelines as topic [Mesh:NoExp] OR Practice guidelines as topic[mh] OR Health planning guidelines[mh] OR guideline[pt] OR practice guideline[pt] OR consensus development conference[pt] OR consensus development conference, $\mathrm{NIH}$ [pt] OR position statement*[tiab] OR policy statement* [tiab] OR practice parameter*[tiab] OR best practice*[tiab] OR standards[ti] OR guideline[ti] OR guidelines[ti] OR ((practice[tiab] OR treatment*[tiab]) AND guideline*[tiab]) OR CPG[tiab] OR CPGs[tiab] OR consensus*[tiab] OR ((critical[tiab] OR clinical[tiab] OR practice[tiab]) AND (path[tiab] OR paths[tiab] OR pathway[tiab] OR pathways[tiab] OR protoco**[tiab])) OR recommendat*[ti] OR (care[tiab] AND (standard[tiab] OR path [tiab] OR paths[tiab] OR pathway[tiab] OR pathways[tiab] OR map[tiab] OR maps[tiab] OR plan[tiab] OR plans[tiab])) OR (algorithm*[tiab] AND (pharmacotherap*[tiab] OR therap*[tiab] OR treatment*[tiab] OR intervention*[tiab]))).

The review was reported in line with the Preferred Reporting Items for Systematic Reviews and Meta-Analyses (PRISMA) statement.

\section{Eligibility criteria}

Guidelines/consensus statements were included if they met the following criteria:

(1) addressed issues about the management of $\mathrm{PNH}$;

(2) were published in English, Portuguese, French, Italian or Spanish;

(3) their full-text was available.

Exclusion criteria were:

(1) guideline/consensus focused on a specific topic considered irrelevant to the management of $\mathrm{PNH}$, such as screening guidelines;

(2) narrative reviews;

(3) draft or unpublished guidelines, discussion papers and personal opinions.

In case of multiple updated versions of a guideline/consensus statement, the most recent one was included.

\section{Data extraction and quality assessment}

Two independent reviewers conducted the search in databases using the predefined strategy and selected the studies. In cases without a consensus, a third reviewer would be consulted about the eligibility and responsible for the final decision. All titles and/or abstracts were reviewed to determine if they met the eligibility criteria. When citations met the criteria, the full-text articles were retrieved and reviewed. The authors collected the main features of each guideline/consensus statement (e.g., year of publication, country/region, and treatment recommendations).

The Appraisal of Guidelines for Research and Evaluation (AGREE) II instrument was used to determine the quality of each guideline included in the systematic review (The AGREE Next Steps Consortium, 2017; Brouwers et al., 2016). The AGREE 
II consists of 23 key items organized within 6 domains followed by 2 global rating items. Each domain captures a unique dimension of guideline quality: 'Scope and Purpose'; 'Stakeholder Involvement'; 'Rigor of Development'; 'Clarity of Presentation'; 'Applicability'; and 'Editorial Independence'. Each of the AGREE II items are rated on a 7-point scale (1-strongly disagree to 7strongly agree). A quality score is calculated for each of the six AGREE II domains. The six domain scores are independent and should not be aggregated into a single quality score. Domain scores are calculated by summing up all the scores of the individual items in a domain and scaling the total as a percentage of the maximum possible score for that domain. Two reviewers independently rated the items (The AGREE Next Steps Consortium, 2017). In this publication the evaluators' consensus scores are presented for each key item of AGREE II.

\section{Results}

\section{Selection of guidelines}

The electronic search strategy identified 184 publications (Figure 1). After screening and review, a total of 18 guidelines and consensus statements were identified for a detailed analysis. Of these, eight guidelines/consensus were included (Table 1), of which one was developed by an international group, two were developed in Spain, and one each in Turkey, German, Argentina, Australia and the United Kingdom. The languages used were English and Spanish.

Table 2 summarizes the main treatments recommended by the guidelines/consensus. PNH treatment can be classified into three main groups: supportive treatment, disease-modifying treatment and potentially curative treatment (Sahin et al., 2016).

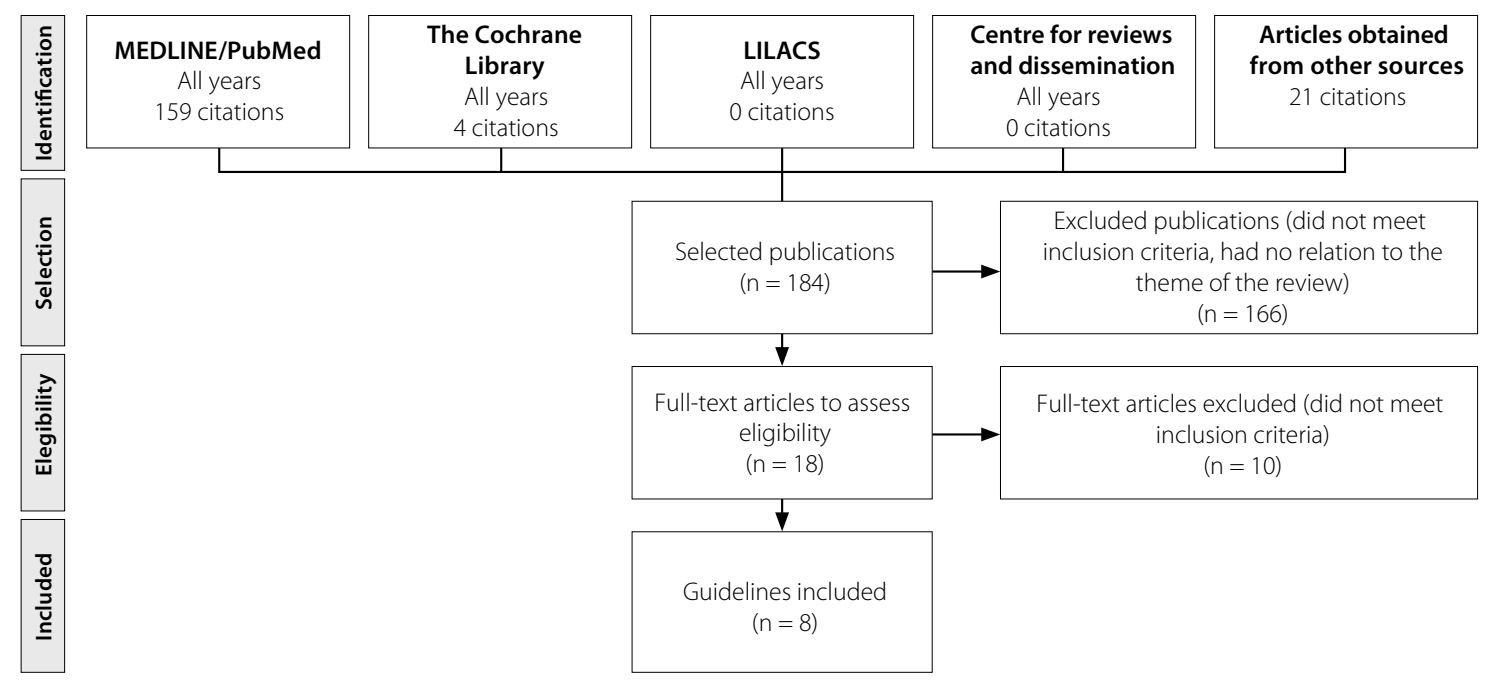

Figure 1. Selection of guidelines for inclusion in the systematic review.

Table 1. Guidelines and consensus included

\begin{tabular}{|c|c|c|c|}
\hline Organization/society/authors & Guideline name(s) & $\begin{array}{l}\text { Year of } \\
\text { publication }\end{array}$ & Country \\
\hline 1. PNH Education and Study Group (Sahin et al., 2016) & PESG PNH guideline & 2016 & Turkey \\
\hline $\begin{array}{l}\text { 2. Sociedad Española de Hematología y Hemoterapia } \\
\text { (Villegas et al., 2016) }\end{array}$ & $\begin{array}{l}\text { Spanish consensus statement for diagnosis and } \\
\text { treatment of PNH }\end{array}$ & 2016 & Spain \\
\hline $\begin{array}{l}\text { 3. Grupo Español para el Estudio de Hemoglobinuria } \\
\text { Paroxística Nocturna por Citometría de Flujo } \\
\text { (Morado, 2010) }\end{array}$ & $\begin{array}{l}\text { PNH: New treatments and general guidelines for } \\
\text { diagnosis }\end{array}$ & 2010 & Spain \\
\hline $\begin{array}{l}\text { 4. Deutsche Gesellschaft für Hämatologie und } \\
\text { Medizinische Onkologie (Schubert et al., 2012) }\end{array}$ & $\mathrm{PNH}$ & 2012 & Germany \\
\hline $\begin{array}{l}\text { 5. International PNH Interest Group (Parker et al., } \\
\text { 2005) }\end{array}$ & $\begin{array}{l}\text { Diagnosis and management of paroxysmal } \\
\text { nocturnal hemoglobinuria }\end{array}$ & 2005 & $\begin{array}{l}\text { Several } \\
\text { countries }\end{array}$ \\
\hline $\begin{array}{l}\text { 6. Australian Government (Australian Government. } \\
\text { Department of Health and Ageing, 2010) }\end{array}$ & $\begin{array}{l}\text { Guidelines for the treatment of PNH through the Life } \\
\text { Saving Drugs Program }\end{array}$ & 2010 & Australia \\
\hline $\begin{array}{l}\text { 7. Grupo Argentino de Interés en HPN (Grupo } \\
\text { Argentino de Interés en HPN, 2013) }\end{array}$ & $\begin{array}{l}\text { PNH: Consenso Argentino de Diagnóstico y } \\
\text { Tratamiento }\end{array}$ & 2013 & Argentina \\
\hline 8. $\quad$ BMJ Best Practice (Weitz, 2017) & $\mathrm{PNH}$ & 2017 & $\begin{array}{l}\text { United } \\
\text { Kingdom }\end{array}$ \\
\hline
\end{tabular}

PNH: paroxysmal nocturnal hemoglobinuria; HPN: hemoglobinuria paroxística nocturna. 


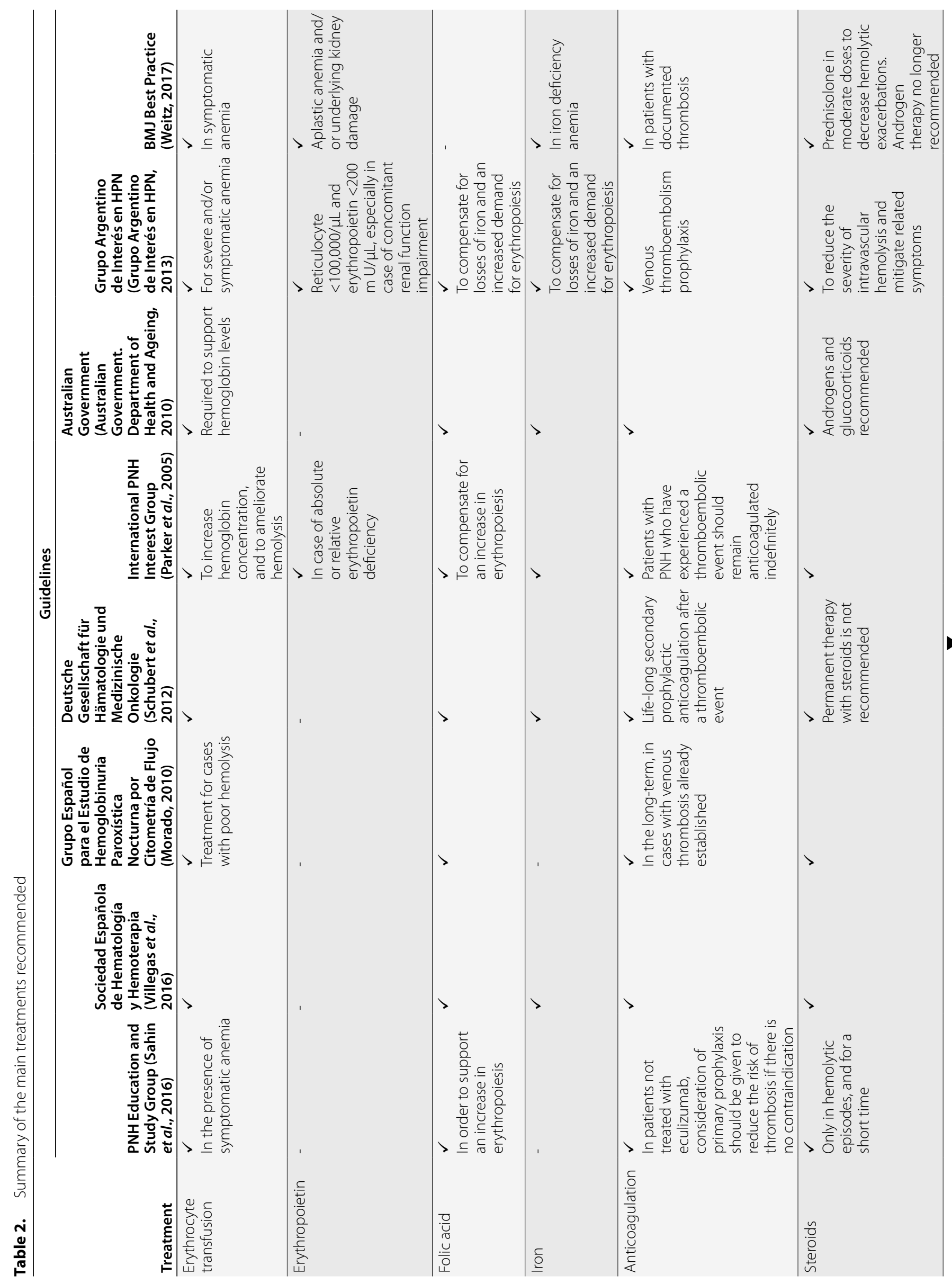




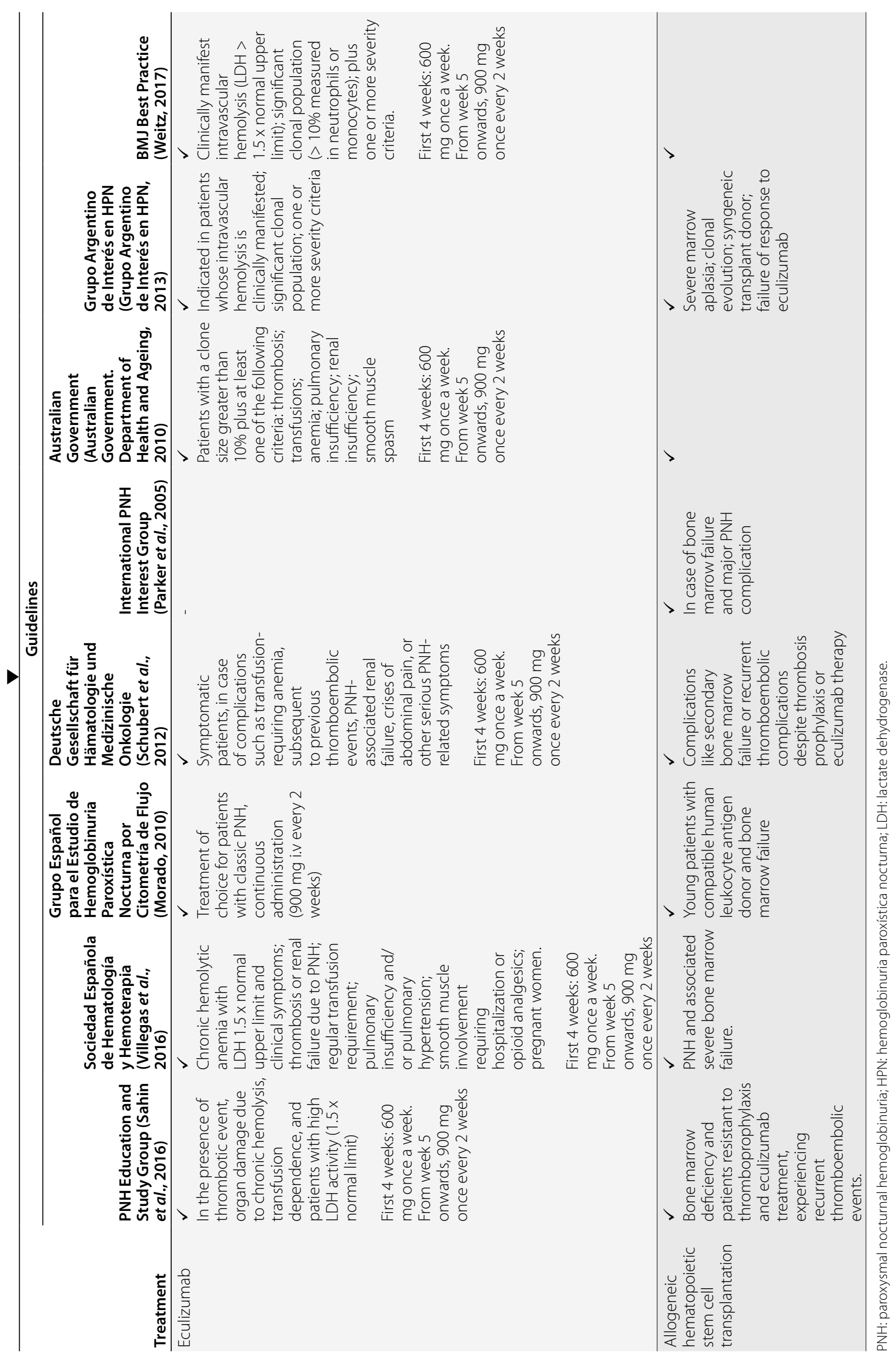




\section{Supportive treatment}

The supportive treatment includes erythrocyte transfusion and iron, vitamin B12 and folic acid supplementation, erythropoietin, anticoagulant treatment and steroids, including glucocorticoids and androgens. Steroids could be used in the short term for a non-recurring hemolytic episode. However, the dose should be reduced rapidly and tapered gradually.

Continuous therapy with steroids is not recommended. Erythrocyte transfusion and anticoagulant treatment are indicated by all guidelines and consensus. The treatment with erythropoietin is suggested by three guidelines only (Parker et al., 2005; Lazarowski et al., 2013; Weitz, 2017). All but one (Weitz, 2017) guideline recommend folic acid or iron supplementation and two guidelines do not recommend (Sahin et al., 2016) or do not mention (Villegas et al., 2016) iron supplementation.

\section{Disease-modifying treatments}

The recommendations for the prescription of eculizumab were consistent in all but one guideline.

The only guideline (Parker et al., 2005) that did not recommend eculizumab was published in 2005 (before the approval of eculizumab in patients with $\mathrm{PNH}$ ) and indicated promising results with the studies conducted th that time with this treatment.

The specificity of the indications cited in the guidelines ranged from the treatment of classical PNH to very specific indications, as presented in Table 2. Regarding dosage, all guidelines that mention the protocol of treatment are unanimous in indicating $600 \mathrm{mg}$ per week in the first 4 weeks, 900 $\mathrm{mg}$ in the 5th week and then continuing with a $900 \mathrm{mg}$ dose every 2 weeks (Villegas et al., 2016; Sahin et al., 2016; Schubert et al., 2012; Australian Government. Department of Health and Ageing, 2010; Weitz, 2017). The Argentine guideline does not mention posology (Brodsky et al., 2013) and one Spanish refers only to the maintenance dose (900 mg every 2 weeks) (Morado et al., 2010).

\section{Potentially curative treatment}

All guidelines acknowledged allogeneic hematopoietic stem cell transplantation as the only potentially curative treatment for PNH and noticed substantial transplantation-associated morbidity and mortality, therefore restricting the indication of stem cell transplantation to a selected group of patients. When specified, indications for transplantation in each guideline are presented in Table 2.

\section{Guidelines appraisal}

The AGREE II scores for each domain applied in the selected guidelines and consensus are provided in Table 3. Regarding the scope and purpose, only three guidelines (Villegas et al., 2016; Australian Government. Department of Health and Ageing, 2010; Brodsky et al., 2013) stated their overall objectives properly. Health questions and target populations were generally described. For stakeholder involvement, all guidelines lacked a description of patients' preferences and the target users were clearly defined only by three guidelines (Australian Government. Department of Health and Ageing, 2010; Brodsky et al., 2013; Weitz, 2017). Within the rigor of development domain, only one consensus (Villegas et al., 2016) mentioned a systematic method of searching for evidence, but did not describe the strategy used. No guideline described its procedures for updating guidelines. Regarding the clarity of presentation, the different options for management of PNH are clearly presented in all guidelines. The scores were the lowest for applicability and no guideline described facilitators and barriers to its applications. Only three guidelines informed about editorial independence and described possible conflicts of interest (Villegas et al., 2016; Morado, 2010; Weitz, 2017).

\section{Discussion}

This systematic review explores the quality and content of published guidelines and consensus concerning the management of $\mathrm{PNH}$. The results suggest a homogeneity in the clinical recommendations for PNH treatment. In general the publications recommended supportive treatment, eculizumab and allogeneic hematopoietic stem cell transplantation. Regarding supportive treatment, the recommendations varied slightly with respect to treatment with erythropoietin and folic acid and iron supplementation, but were consistent for erythrocyte transfusion and anticoagulant treatment. The criteria used to indicate support measures did not differ from those recommended in other hematological conditions. Although of controversial application, corticosteroids were recommended by all evaluated guidelines aiming to reduce the intensity of hemolysis episodes, being used for short periods. Eculizumab was recommended by all guidelines except for one published before it was approved. Until the approval of eculizumab as an orphan drug in 2007 the treatment for PNH in patients not undergoing transplantation was primarily symptomatic. Eculizumab changed the therapeutic approach to PNH. Besides its risk, allogeneic hematopoietic stem cell transplantation was indicated by all guidelines as the only potentially curative treatment for $\mathrm{PNH}$, but is limited to a subset of patients, especially those with bone marrow failure.

Despite the general homogeneity of information on therapeutic options in $\mathrm{PNH}$, the methodological quality of guidelines was heterogeneous and limited. Most guidelines were developed by PNH study groups, which contributes to a favorable note regarding the expertise of the guideline development group.

Within the rigor of development domain, one consensus mentioned a systematic method of searching for evidence, but did not describe the strategy used. No guideline described its 


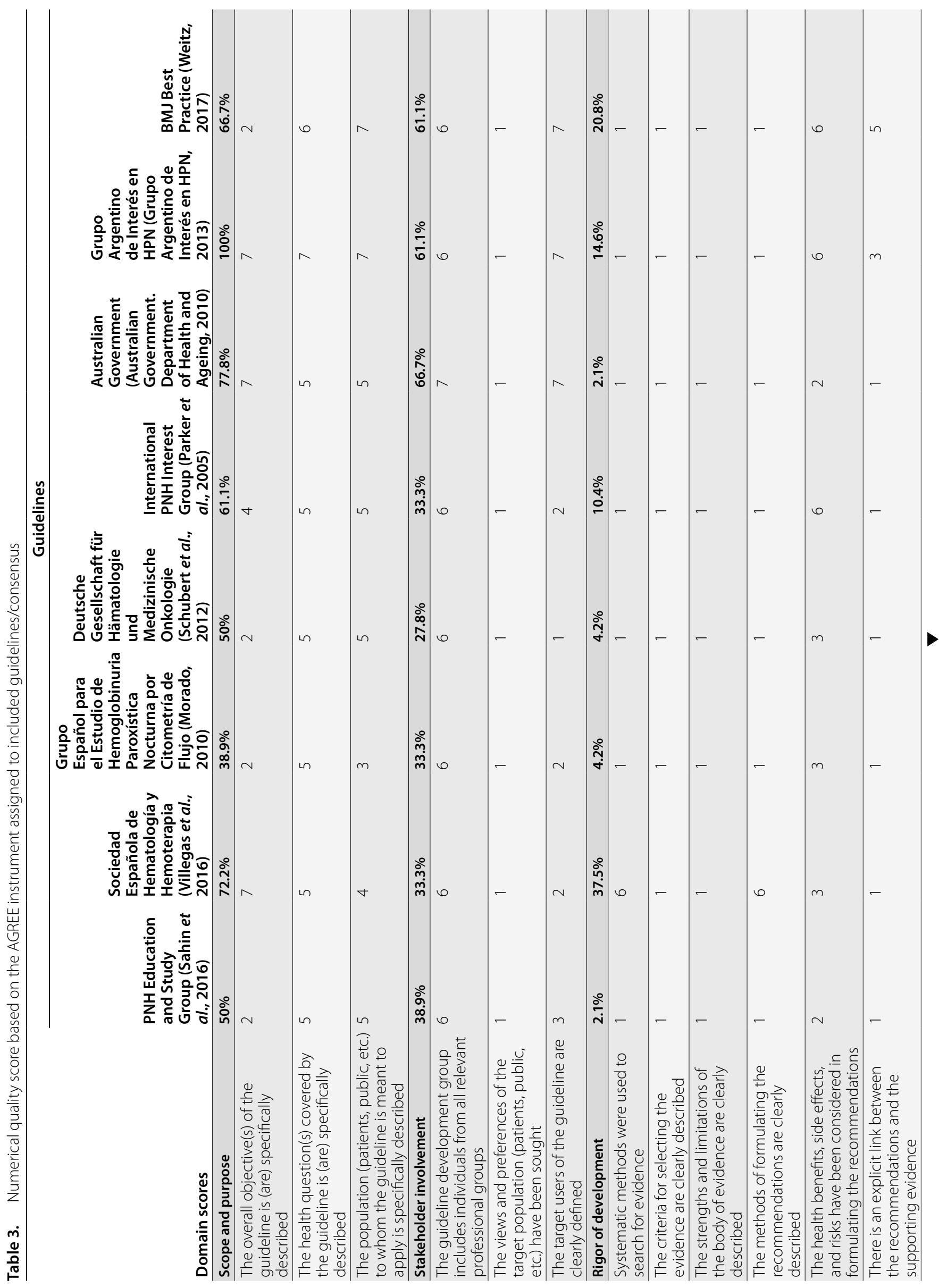




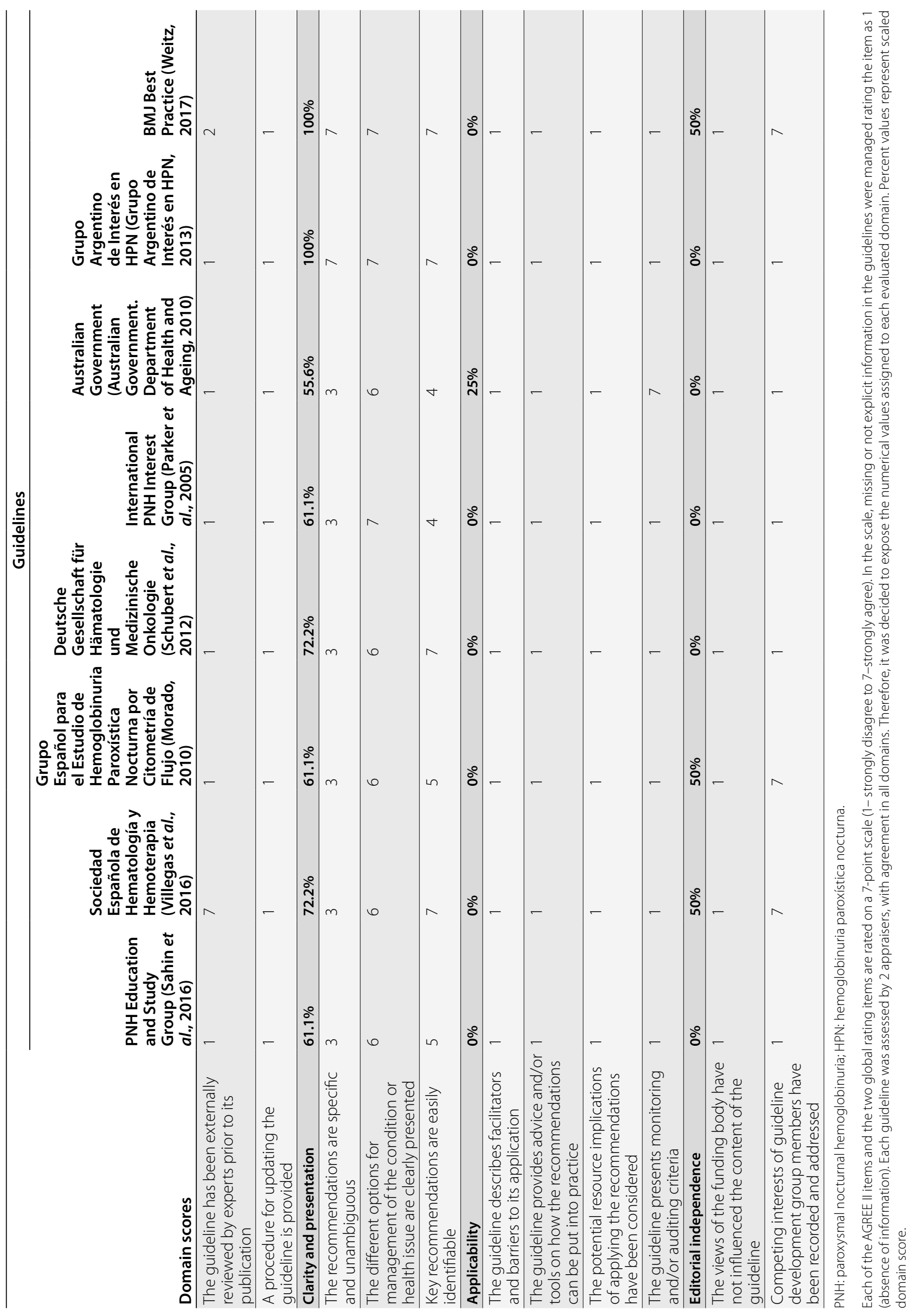


procedures for updating guidelines. Regarding clarity of presentation, the different options for management of PNH are clearly presented in all guidelines. The scores were the lowest for applicability and no guideline described facilitators and barriers to its applications. Only three guidelines informed about editorial independence and described possible conflicts of interest (Villegas et al., 2016; Morado, 2010; Weitz, 2017).

A strength of this review is that, to our knowledge, this is the first publication assessing the quantity and quality of guidelines on PNH management. Although a broad search strategy was performed in eight electronic databases, this study is limited by the fact that some clinical guidelines are published in local databases, being difficult to identify them. One limitation of this report is that PRISMA guidelines focus on the reporting of reviews evaluating randomized clinical trials. It can also be used as a basis for reporting systematic reviews of other types of research, but particularly evaluations of interventions (Moher et al., 2009; Liberati et al., 2009). To date, validated tools to assess systematic reviews of treatment guidelines were not published.

\section{Conclusion}

Despite the low and heterogeneous methodological quality, in general the comparison of guidelines and consensus for $\mathrm{PNH}$ management showed consistent recommendations regarding supportive care, eculizumab and hematopoietic stem cell transplantation.

\section{Acknowledgements}

We thank SENSE Company Brazil for editorial support in developing the drafts of this manuscript. The authors were responsible for critical revisions of the manuscript for the important intellectual content. The authors are deeply indebted to Dr. Paulo Alvarenga, former Alexion Associate Director, Medical Affairs PNH, for his invaluable contribution to the review of this publication.

\section{References}

Australian Government. Department of Health and Ageing. Guidelines for the treatment of Paroxysmal Nocturnal Haemoglobinuria (PNH) through the Life Saving Drugs Program. 2010.

Brodsky RA. Paroxysmal Nocturnal Hemoglobinuria. Blood. 2014;124(18):2804-11.

Brodsky RA, Young NS, Antonioli E, Risitano AM, Schrezenmeier H, Schubert $J$, et al. Multicenter Phase 3 Study of the Complement Inhibitor Eculizumab for the Treatment of Patients With Paroxysmal Nocturnal Hemoglobinuria. Blood. 2008;111(4):1840-7.

Brouwers MC, Kerkvliet K, Spithof K, AGREE Next Steps Consortium. The AGREE Reporting Checklist: A Tool to Improve Reporting of Clinical Practice Guidelines. BMJ. 2016;352:11152.

De Latour RP, Mary JY, Salanoubat C, Terriou L, Etienne G, Mohty M, et al. Paroxysmal Nocturnal Hemoglobinuria: Natural History of Disease Subcategories. Blood. 2008;112(8):3099-106.
Gliklich R, Dreyer N, Leavy M, eds. Registries for Evaluating Patient Outcomes: A User's Guide. 3rd Edition. Two volumes. Rockville (MD): Agency for Healthcare Research and Quality; 2014.

Brodsky A, Cappellino A, Molinas F, Nucifora E, Real JJ, Rocaspana A, et al. Hemoglobinuria Paroxistica Nocturna. Consenso Argentino de Diagnostico y Tratamiento. Grupo Argentino de Interes en HPN. 2013.

Hill A, Kelly RJ, Hillmen P. Thrombosis in Paroxysmal Nocturnal Hemoglobinuria. Blood. 2013;121(25):4985-96.

Hill A, Kelly RJ, Kulasekararaj AG, Gandhi SA, Mitchell LD, Elebute M, et al. Eculizumab in Paroxysmal Nocturnal Hemoglobinuria (PNH): A Report of All 153 Patients Treated in the UK. Blood. 2012;120(21):3472.

Hillmen P, Lewis SM, Bessler M, Luzzatto L, Dacie JV. Natural History of Paroxysmal Nocturnal Hemoglobinuria. N Engl J Med. 1995;333(19):1253-8.

Hillmen P, Muus P, Dührsen U, Risitano AM, Schubert J, Luzzatto L, et al. Effect of the Complement Inhibitor Eculizumab on Thromboembolism in Patients With Paroxysmal Nocturnal Hemoglobinuria. Blood. 2007;110(12):4123-8.

Lee SE, Park SS, Jeon YW, Yoon JH, Cho BS, Eom KS, et al. Outcomes of Allogeneic Stem Cell Transplantation in Patients With Paroxysmal Nocturnal Hemoglobinuria With or Without Aplastic Anemia Eur J Haematol. 2017;99(4):336-43.

Liberati A, Altman DG, Tetzlaff J, Mulrow C, Gøtzsche PC, loannidis JPA, et al. The PRISMA Statement for Reporting Systematic Reviews and MetaAnalyses of Studies That Evaluate Health Care Interventions: Explanation and Elaboration. PLoS Med. 2009;6(7):e1000100.

Moher D, Liberati A, Tetzlaff J, Altman DG, PRISMA Group. Preferred Reporting Items for Systematic Reviews and Meta-Analyses: The PRISMA Statement. PLoS Med. 2009;6(7):e1000097.

Morado M, Subirá D, Rubio ML, Grupo Español para el Estudio de Hemoglobinuria Paroxística Nocturna por Citometría de Flujo. Hemoglobinuria Paroxística Nocturna: Nuevos Tratamientos y Recomendaciones Generales para Su Diagnóstico. Med Clin (Barc). 2010;134(8):369-74.

Parker CJ. Paroxysmal Nocturnal Hemoglobinuria. Curr Opin Hematol. 2012;19(3):141-8

Parker CJ. Paroxysmal Nocturnal Hemoglobinuria: An Historical Overview. Hematology Am Soc Hematol Educ Program. 2008:93-103.

Parker C, Omine M, Richards S, Nishimura J, Bessler M, Ware R, et al. Diagnosis and management of paroxysmal nocturnal hemoglobinuria. Blood. 2005;106(12):3699-709.

Risitano AM, Rotoli B. Paroxysmal Nocturnal Hemoglobinuria: Pathophysiology, Natural History and Treatment Options in the Era of Biological Agents. Biologics. 2008;2(2):205-22.

Socié G, Schrezenmeier H, Muus P, Lisukov I, Röth A, Kulasekararaj A, et al. Changing Prognosis in Paroxysmal Nocturnal Haemoglobinuria Disease Subcategories: An Analysis of the International PNH Registry. Intern Med J. 2016;46(9):1044-53.

Sahin F, Akay OM, Ayer M, Dal MS, Ertop S, Ilhan O, et al. Pesg PNH Diagnosis, Follow-Up and Treatment Guidelines. Am J Blood Res. 2016;6(2):19-27.

Schubert J, Bettelheim P, Brümmendorf A, Schrezenmeier H, Stüssi G. Paroxysmal Nocturnal Hemoglobinuria (PNH). Recommendations from the Society of Haematological and Oncological Diseases. 2012.

The AGREE Next Steps Consortium. Appraisal of Guidelines for Research \& Evaluation II. 2017:52.

Villegas A, Arrizabalaga B, Bonanad S, Colado E, Gaya A, González A, et al. Consenso Espanõl para el Diagnóstico y Tratamiento de la Hemoglobinuria Paroxística Nocturna. Med Clin (Barc). 2016;146(6):278.e1-7.

Weitz I. Hemoglobinúria paroxística noturna. BMJ Best Pract [homepage na internet]. 2017. Available from: https://bestpractice.bmj.com/topics/ptbr/894/. Access on: May, 2020. 